\title{
ORIGINAL PAPER \\ Information load in escalation situations: combustive agent or counteractive measure?
}

\author{
Peter Gordon Roetzel ${ }^{1,2} \cdot$ Burkhard Pedell $^{2}$ - Daniel Groninger ${ }^{2}$ \\ Published online: 14 May 2020 \\ (c) The Author(s) 2020
}

\begin{abstract}
This experimental study analyzes how a key factor, information load, influences decision making in escalation situations, i.e., in situations in which decision makers reinvest further resources in a losing course of action, even when accounting information indicates that the project is performing poorly and should be discontinued. This study synthesizes prior escalation research with information overload and investigates how different levels of information load influence the escalation of commitment. Our findings reveal a U-shaped effect of information load: When decision makers face negative feedback, a higher information load mitigates the escalation tendency up to a certain point. However, beyond this point, more information reinforces the escalation tendency. Moreover, we find that the type of feedback affects self-justification, and we find a negative and significant interaction between information load and self-justification in negative-feedback cases. Thus, studies investigating escalation of commitment should control for self-justification and information load when utilizing high levels of information load. Finally, in the positive-feedback condition, higher information load encourages decision makers to continue promising courses of action, i.e., increases decision-making performance.
\end{abstract}

Keywords Escalation of commitment - Experimental research - Information load · Responsibility $\cdot$ Self-justification

JEL Classification C91 $\cdot$ D80 $\cdot$ M20 $\cdot$ M41

Peter Gordon Roetzel

peter.roetzel@th-ab.de

1 Technische Hochschule Aschaffenburg, Würzburger Str. 45, 63743 Aschaffenburg, Germany

2 University of Stuttgart, Stuttgart, Germany 


\section{Introduction}

Escalation of commitment, i.e., misevaluating negative feedback and preferring to continue with a losing course of action, is "[o]ne of the most robust and costly decision errors addressed in the organizational sciences" (Sleesman et al. 2012). Prior research on escalation of commitment has shifted from questions of why and where to focusing on questions of how (via what mediators) and under which circumstances (in the presence of what moderators) that escalation of commitment occurs (Sleesman et al. 2018).

One of the central elements of escalation situations is the information provided to decision makers. Management reporting and business information systems provide more decision information than ever before (Levitin 2015). Compound annual growth rate between 1987 and 2007 has shown that the increase in the amount of information computed, communicated, and stored per capita is $58 \%$ per annum (Hilbert and Lopez 2011). Even when we factor in the concurrent progress in methods and technology that are used to process and analyze information (Levitin 2015), there is still an upward trend in information load.

Research on escalation of commitment started with the seminal work of Staw (1976). In these first experiments, decision makers faced a very low level of information load (Bazerman et al. 1982; Fox and Staw 1979; Staw 1981, 1976). Some of the subsequent experiments included new treatments and, accordingly, entailed a higher information load (see Table 1 in Sect. 2.3).

In such experiments, participants were exposed to different levels of information load as new treatments were included. However, these experimental extensions merely increased the information load without controlling for its potential impact. Simon (1971, p. 40) stated, "What information consumes is rather obvious: it consumes the attention of its recipients. Hence a wealth of information creates a poverty of attention, and a need to allocate that attention efficiently among the overabundance of information sources that might consume it". Two review studies showed that information load affects management behavior with mostly negative impacts, from misinvestment to physical and emotional stress (Eppler and Mengis 2004; Roetzel 2019). There comes a point when the negative effects outweigh the potential benefits of additional information (information overload), producing an inverse U-shaped relationship between information load and decision-making performance (Driver et al. 1998; Schroder et al. 1967). There is no indication that decision making in escalation situations can be protected from such information overload effects.

Given this, we still have little evidence regarding how participants react when higher levels of information load are provided in escalation situations. However, neither the studies with low levels of information load nor those with moderate levels controlled for single or interaction effects that the information load level provided had on the escalation tendency (Bazerman et al. 1982; Schulz and Cheng 2002; Seybert 2010). Prior research has focused on a number of factors but not on information processing in escalation situations: information search and selection (e.g., Schultze et al. 2012), on how decision makers are distracted by incoherent 
information (e.g., Denison 2009; Schultze et al. 2012), and on how decision makers ignore information that does not confirm their prior actions (Conlon and Parks 1987; Staw 1981). This means we still do not know how the total set of information provided (i.e., information load) affects decision making. Thus, we suggest that there has been an omission in the literature because the level of information load is treated as a constant in prior studies, and to date, no study has adopted an information (over-)load perspective or addressed information load as a treatment variable.

It is important for managers and researchers to understand the relationship between escalation of commitment and the information load in a decision situation because the information load in day-to-day business continuously increases, and has major impact (e.g., Levitin 2014; Shapiro and Varian 2013). Decision makers who face overly high levels of information load might make suboptimal decisions and exacerbate the escalation of commitment.

In this study, we address the impact of information load on decision makers' escalation of commitment by analyzing how decision makers' escalation tendency shifts when different levels of information load are provided. Higher levels of information load that indicate poor performance (negative feedback) might increase a decision maker's cognitive dissonance (Festinger 1957). Following self-justification theory (Staw 1976), this increases the likelihood of escalating commitment. In the baseline case of Staw (1976), individuals tend to allocate additional resources to a formerly chosen investment when they receive negative feedback. In this study, we investigate how this mechanism changes under different information load and feedback conditions.

Our study contributes to the information load and escalation of commitment literature by investigating the relationship between information load and decision making in escalation situations. We synthesize existing escalation research (e.g., Sleesman et al. 2012, 2018) with information overload research (e.g., Eppler and Mengis 2004, Roetzel 2019). Our findings reveal a U-shaped effect of information load. When decision makers face negative feedback, higher information load mitigates the escalation tendency up to a certain point. Beyond this point, more information leads to higher escalation behavior. The result is a U-shaped relationship between information load and the allocation of additional resources to a losing course of action. This outcome corresponds to an inverse U-shaped relationship between information load and decision-making performance (e.g., Driver et al. 1998; Schroder et al. 1967). In addition, we find that the type of feedback affects self-justification, and we find a negative and significant interaction between information load and self-justification in negative-feedback cases. Our findings for the negative-feedback condition deepen our knowledge about the role of information processing in decision making in escalation situations. Moreover, it addresses a gap in the literature and emphasizes that subsequent research on escalation of commitment should consider the possible effects of information load on decision-making behavior.

Beyond our analysis of the negative-feedback condition, we investigated the effect of information load on decision-making performance in the positive-feedback condition. We found that a higher information load encouraged decision makers to continue promising courses of action. 
We argue that understanding the influence of information load in negative and positive feedback situations is an important issue for researchers and practitioners. Researchers can use this in the design of experiments investigating escalation of commitment and investment decisions in general. Practitioners can use this in relation to the design of effective management controls to ensure that accounting information is used to support optimal investment and disinvestment decisions. More specifically, it is important to understand how management controls and management information systems can contribute to mitigating escalation tendencies in negative feedback situations and, where appropriate, encouraging disinvestment decisions.

\section{Theory and hypotheses}

\subsection{Escalation of commitment}

Escalation of commitment describes the tendency to persist in a failing course of action despite negative feedback, such as accounting information indicating that a project is performing poorly (Cheng et al. 2003; Kadous and Sedor 2004), i.e., "throwing good money (or more generally, resources) after bad" (Sleesman et al. 2012, p. 541).

Based on Festinger's (1957) cognitive dissonance theory and Kiesler's (1971) psychological commitment theory, self-justification theory predicts that decision makers will escalate their commitment to a losing course of action (negative-feedback condition) to justify their prior decisions, as well as their actions, beliefs, and feelings. When decision makers receive negative feedback, they experience cognitive dissonance because negative information that indicates poor performance conflicts with their positive self-perception. This effect arises from the positive self-perception of the decision maker, which she or he wishes to maintain. These decision makers shift their focus away from the organization's superior goals toward the personal goal of protecting their positive self-image by justifying their prior decisions. Self-justification is accepted as a driver of escalation of commitment. The decision makers who are responsible for an initial investment decision tend to invest additional funds in a poorly performing project to rationalize their prior behaviors, decisions, and investments (e.g., Schulz and Cheng 2002; Schultz-Hardt et al. 2009; Staw 1981).

\subsection{Information overload}

According to Roetzel's (2019) definition, “[i]nformation overload is a state in which a decision-maker faces a set of information [...] comprising the accumulation of individual informational cues of differing size and complexity that inhibit the decision-maker's ability to optimally determine the best possible decision" (p. 484).

The literature suggests that the relationship between decision-making performance and information load is an inverted U-curve with a maximum level of possible decision-making performance. Decision-making performance is predicted to 
improve between zero and the point at which human information-processing capacity is reached. Beyond this point, the decision maker is provided with more information than he or she is able to process. This state is called information overload (e.g., Eppler and Mengis 2004; Roetzel 2019).

Decision makers face a trade-off when receiving more unequivocal information, i.e., information that supports the best decision alternative: On the one hand, this information reduces ambiguity in the decision situation as it makes the decision situation more clear, consequently increasing decision-making performance. On the other hand, the processing of more information demands a higher cognitive capacity, and decision-making performance is negatively affected by cognitive load. In line with this trade-off, research about information overload indicates that, beyond a certain point, additional information leads to a reduction in decision-making performance (e.g., Driver et al. 1998; Schroder et al. 1967; Roetzel and Fehrenbacher 2019).

\subsection{Information load in the negative-feedback condition}

A central prerequisite for individuals' development of self-justification is that they face negative feedback. Existing research on escalation of commitment has been inconsistent regarding the number of information cues used for negative feedback. Table 1 provides an overview of the different numbers of information cues used. While existing research has investigated information-searching behavior (e.g., Schultze et al. 2012) and how decision makers ignore information that does not confirm their prior actions (e.g., Conlon and Parks 1987; Sleesman et al. 2012; Staw 1981), it has not considered the set of information provided (i.e., the information load).

Building on the concept of information overload and on self-justification theory, we would expect information load to have several effects in escalation situations. First, applying the argument that information load has an inverse U-shaped effect on decision-making performance regarding an escalation situation with negative feedback, we would expect that information load has a U-shaped effect on the allocation of resources to a losing course of action. In this situation, the allocation of more resources is associated with lower decision-making performance.

Providing more information is reported to reduce ambiguity, which can reinforce the poor prospects for allocating additional resources to a losing course of action (e.g., Bowen 1987) and consequently reduce the allocation of additional resources. At some point cognitive load overweighs this effect and more additional resources are committed to the losing course of action.

At the same time, an increasing load of negative information might increase the signal of poor performance in the chosen course of action so that cognitive dissonance emerges and may exacerbate the decision makers' tendency to justify themselves (Sleesman et al. 2012; Staw 1976, 1981). As self-justification increases, we would expect decision makers to commit more resources to the losing course of action to maintain a positive self-image. 


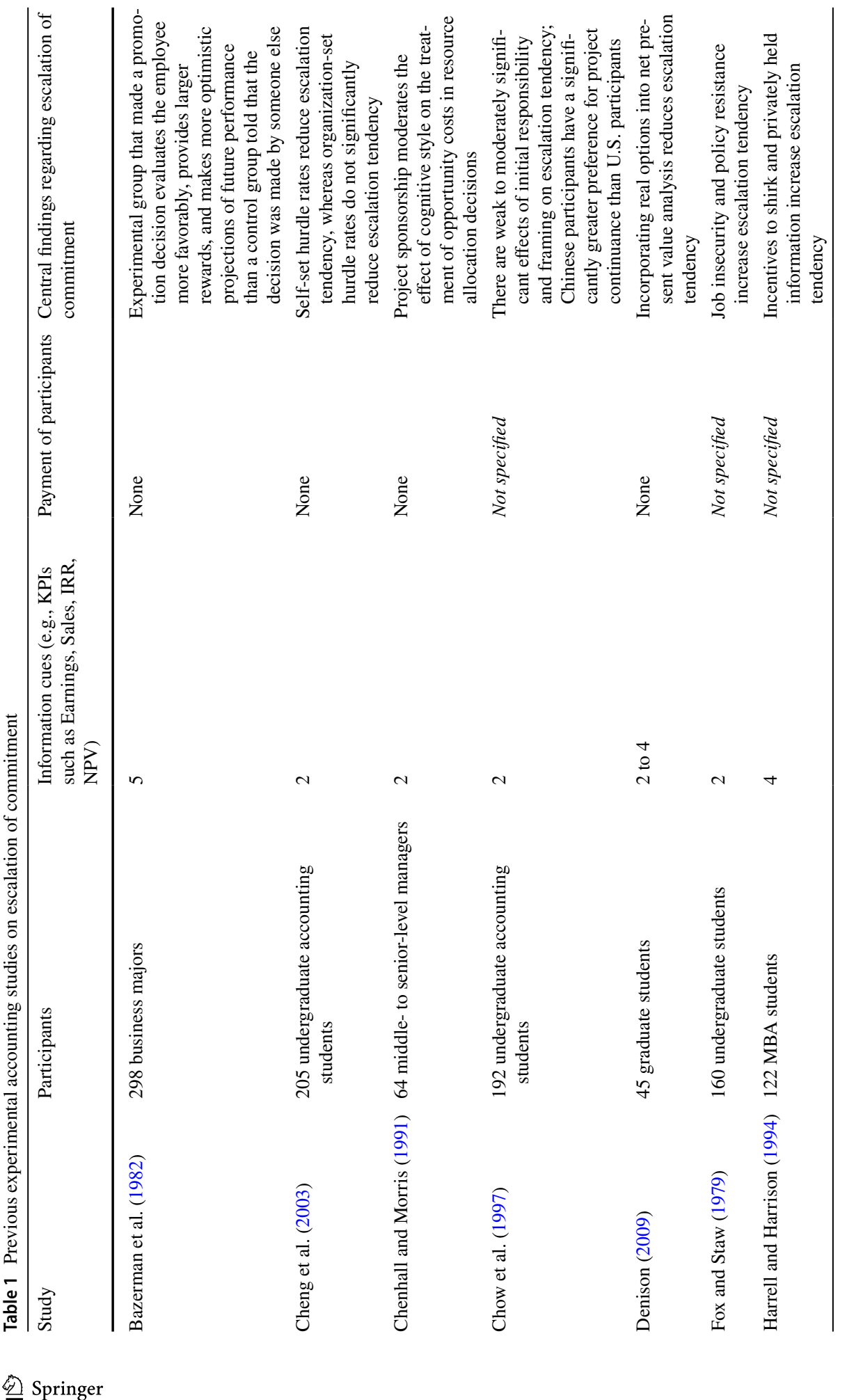




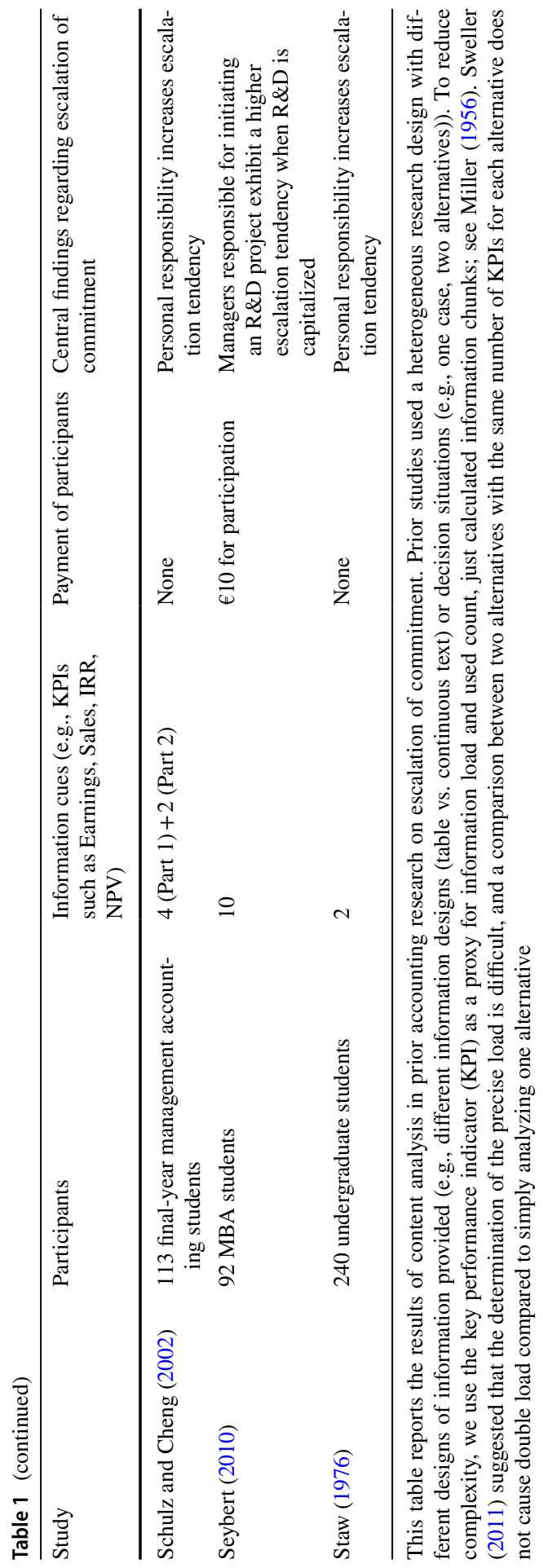


Given this we suggest that decision makers reduce their escalating tendency with an increasing load of negative information up to a certain level of information load because ambiguity is reduced. Beyond this point, providing even more negative information might increase the escalation tendency for two reasons. First, cognitive load increases. Second, growing evidence of having chosen wrongly increases cognitive dissonance, thus fortifying the decision maker's urge to protect his or her positive self-image by justifying prior decisions. For these reasons we propose a U-shaped relationship:

H1 When facing negative feedback, increasing information load reduces the escalation of commitment up to a certain point and increases the escalation of commitment from that point on

In relation to cognitive dissonance we expect that providing more negative information (information load) influences self-justification and that information load and self-justification interact in their effect on decision-making performance. However, due to the expectation that nonlinearities are involved in this interaction, we do not formulate a hypothesis but confine ourselves to the following research question:

RQ1 When facing negative feedback, how do information load and self-justification interact in influencing escalation of commitment?

\subsection{Information load in the positive-feedback condition}

In the positive-feedback condition, decision makers only receive confirmatory information, indicating success of the initial investment supporting the allocation of further resources to this investment. Consequently, the information provided does not provide grounds for cognitive dissonance and self-justification. In the positive-feedback condition, we build our expectation only on the information overload mechanism. According to the inverse U-shaped relationship between information load and decision-making performance (e.g., Eppler and Mengis 2004; Roetzel 2019) we would expect an inverse U-shaped relationship between information load and the allocation of resources. In the positive-feedback condition, in contrast to the negative-feedback condition, the allocation of more resources is associated with a higher decision-making performance.

H2 When facing positive feedback, increasing information load increases the resources allocated to a promising course of action up to a certain point and decreases them from that point on

To sum up, we suggest that information load might affect decision-making performance both in negative feedback situations regarding (dis-)investment 
decisions (H1, RQ1) and in positive feedback situations regarding investment decisions (H2).

\section{Research design and methods}

\subsection{Design}

We have drawn on the seminal design of Staw (1976) and his two-option case. We have used the same values for accounting information and the same experimental procedure. Following the recommendations of Tsang and Kwang (1999), we have extended the measurement and analysis and designed this study with a different population as a "generalization and extension" (Tsang and Kwang 1999, Fig. 1).

Our experiment consists of a 2 (consequence of initial decision: positive feedback/positive accounting information vs. negative feedback/negative accounting information) $\times 4$ (information load: 2, 4, 8, and 12 KPIs) between-subjects design. All treatments are manipulated across the participants. The participants are randomly assigned to one of the between-subjects conditions. The escalation of commitment is characterized by situations with negative feedback (negative accounting information) only. In the positive-feedback condition, participants only receive positive accounting information.

This study uses four levels of information load: 2, 4, 8, and 12 KPIs. Drawing on Simnet (1996), we use increasing information load levels by increasing the number of accounting KPIs. Following Chewning and Harrell (1990), we use financial ratios as decision cues. The original case, developed by Staw (1976), consisted of 2 KPIs over 8 business years, implying a very low level of information load. Simnet's (1996) study uses 4 KPIs as baseline case and 10 KPIs to investigate information overload. Chewning and Harrell (1990) use multiples of 2 KPIs to design their load treatment (4 KPIs, 6 KPIs, and 8 KPIs). We have chosen to use multiples of 4 KPIs, because 4 KPIs is an often-used quantity in many of the extant studies on escalation of commitment (Table 1). Thus, we add multiples of four (8 KPIs, $12 \mathrm{KPIs}$ ) to the original setting (2 KPIs) and our baseline case (4 KPIs): The highest information load in the 12 KPIs group indicates that participants are faced with 12 KPIs for 8 business years, i.e., 96 numbers. This process allows us to cover the range of the number of information cues used in previous studies (Table 1) and to extend this range slightly.

Like existing studies, we do not randomize the order of KPIs (Chewning and Harrell 1990; Simnet 1996). We make this decision because a randomization would interfere with the content-related structure of the KPIs in this setting. Table 7 in Appendix A shows the four treatment groups regarding information load. The group "2 KPI" receives accounting information on earnings and sales. Group "4 KPI" receives the information of the group " 2 KPI" plus EBTA (earnings before taxes and amortization) and EBSA (earnings before interest and tax/sales), drawn from Simnet (1996). In this way the KPIs are linked in content and build on one another.

We select the additional KPIs used by Simnet (1996). These ratios are based on the financial indicators used by Staw (1976), which are earnings and sales. The data 
that we use in the reports are identical to those used in Staw's Adams \& Smith Company case. The only change that we make is to relate the compound KPIs to the financial indicators used by Staw (1976) (i.e., earnings and sales); all other components of the KPIs (e.g., assets, liabilities) are held constant. Following existing research, we do not establish financial objectives for the participants (Bazerman et al. 1982; Schulz and Cheng 2002; Staw 1976). Appendix A displays the KPIs that we use and shows how they are assigned to the different experimental groups. The use of KPIs avoids positive or negative framing of information, which can affect decision making in escalation situations (e.g., Fehrenbacher et al. 2018; Sharp and Salter 1997).

We use unequivocal information, i.e., in the negative feedback condition, all KPIs suggest not investing additional resources in the initially chosen investment project, whereas in the positive feedback condition, all KPIs suggest investing additional resources in the initially chosen investment project. In this way we reduce uncertainty as far as possible within the information set regarding the performance of the investment (Bragger et al. 1998). In doing this we follow existing research on escalation of commitment as we design a situation in which not investing additional resources (or, depending on the setup, disinvesting) is economically rational (e.g., Staw 1976; Schulz and Cheng 2002). We do manipulate the quantity of information, but we do not manipulate the information content in relation to the suggested decision by mixing KPIs with parameters that suggest discontinuing and KPIs with parameters that suggest continuing the initially chosen investment project (unequivocal negative or positive feedback). ${ }^{1}$ We do not vary parameters of additional elements (e.g., total assets) so differences in the financial ratios are driven by differences in Staw's (1976) original KPIs sales and earnings only.

\subsection{Procedure}

We draw our procedure from Staw's (1976) Adams \& Smith case with two extensions. First, the original case of Staw (1976) is represented in our " 2 KPI" treatment condition, which is an exact replication for both the positive- and negative-feedback conditions. We extend this basic condition by increasing the accounting information provided to participants. The accounting information report uses $2,4,8$ or 12 KPIs and displays either generally stable positive economic development for the chosen division (positive feedback) or losses (negative feedback). Following the receipt of feedback, the participants are asked to decide how to allocate an additional $€ 20$ million between continuation of the original funding (i.e., the initially chosen business division) and funding of the other business division. By comparing the additional amounts invested in the initially chosen course in the positive and negative-feedback conditions we can detect the degree to which a decision maker escalates his/her

\footnotetext{
1 However, the information content varies between the 2, 4, 8 and 12 KPI conditions in the sense that additional parameters, such as shareholder equity and total assets, are required to calculate the additional KPIs. This is in line with extant approaches to vary information load (see Sect. 3.1).
} 
commitment (Sleesman et al. 2012; Staw 1976). Second, we extend the number of questions in the post-experimental questionnaire.

All participants are given the history of a hypothetical company, Adams \& Smith, Inc., which is divided into two divisions: consumer and industrial products. To avoid participants' preference for one of the two divisions, the accounting data for the two divisions are economically the same. This study uses the described setting to model free choice that results in personal responsibility.

The task consists of two parts. The first part outlines an initial $€ 10$ million of R\&D funding to promote one of the two divisions, which can then use the funding at will. We provide the participants with accounting information regarding the performance of the two divisions for the past eight-year period (2006-2013). All of the participants are responsible for the initial funding decision and, accordingly, for independently deciding which of the two product divisions should receive the funding.

Previous research has provided sufficient empirical evidence demonstrating the effect of the responsibility for the initial decision on the tendency to escalate commitment (Bazerman et al. 1982; Schulz and Cheng 2002; Staw 1976). Given this we do not use the effect of responsibility as a treatment in this scenario. Rather, we use it as an experimental setting (all the participants determine both the initial and subsequent allocation of resources). To control for responsibility, we draw on Whyte's (1991) approach to measure the participants' self-reported degree of responsibility for the initial funding and the resulting feedback, using a post-experimental questionnaire applying an 11-point Likert scale (Bazerman et al. 1982; Whyte 1991). "Responsibility" is assessed using the following question: "To what extent do you feel responsible for the future development of the product division that you selected?" (0, not at all; 10 , very much).

In the second part of the task, the participants receive either positive or negative feedback regarding the outcome of the initial funding at a point described as three years after the initial resource allocation decision.

Finally, the participants complete a second questionnaire that also applies an 11-point Likert scale. "Self-justification" (manipulation check) is assessed using the following question: "To what extent do you feel the need to justify your initial decision?" ( 0 , not at all; 10 , very strong). Subsequently, the participants are asked to justify their funding decisions briefly. In addition, we ask the participants to indicate how many KPIs they used for their decision making to analyze their information selection behaviors (Schultze et al. 2012). We provide a full list of KPIs depending on their information load condition (2, 4, 8, 12 KPIs), and the participants are asked to check the KPIs that they used for their decision making ("Please mark with an ' $x$ ' where applicable"). This step concludes the experiment.

\subsection{Participants}

We conducted our experiment at a large university. Two hundred and twenty-eight undergraduate and graduate students volunteered to participate. Nine subjects were excluded because of missing information or incomplete questionnaires. We also 
excluded 18 subjects because they wanted to invest more than the allowed maximum, and we were uncertain whether these participants understood the experiment sufficiently. Thus, our final sample consisted of 201 participants. The mean age was 22.43 years $(\mathrm{SD}=3.28)$, and 74 of the participants were female. None of the participants reported having previously participated in a similar study. Elliot et al. (2007) suggest that using students as a proxy is a valid methodological choice. The authors recommend using caution when studying first-year students; no firstyear student participated in our study. Furthermore, existing accounting and management research has indicated that students are justifiable surrogates for managers in decision making or judgment research (Cheng et al. 2003; Clinton 1999; Elliot et al. 2007). In an experiment by List and Mason (2011), CEOs reacted similarly to students in an economic task. Their results indicated that representations of a typical subject are quite similar for CEOs and students. This study used a case that did not require extensive experience to reach a conclusion regarding which decision is economically rational. Following existing studies; the participants were not paid for participation (Table 1).

\subsection{Variables}

In this subsection, we describe the variables used in our analysis. We use Allocation of Resources as our dependent variable (DV). Information Load, Type of Feedback, and Self-Justification are used as independent variables (IV). We also use control variables (CV) such as Age, Gender, and Responsibility In the following, we describe how we measured the variables:

Information Load (IV): This variable is the number of KPIs provided to participants and ranges from 2 to 12 in the four treatment conditions (2 KPI, 4 KPI, 8 KPI, and $12 \mathrm{KPI}$ ) (see Sect. 3.1).

Allocation of Resources (DV): This is the dependent variable and its value represents what participants allocate to the initially chosen division and our proxy for escalation of commitment. The scale is from 0 (=no additional allocation of resources) to 20 (= all available budget).

Self-Justification (IV): This variable is a self-reported measure of a participants' self-justification tendency in the post-experimental questionnaire (Measurement: To what extent do you feel the need to justify your initial decision?" (0, not at all; 10, very strong)). This measure is based on Staw (1976).

Type of Feedback (IV): We coded 1 for negative feedback and 0 for positive feedback.

KPI used (IV): This variable is an ex post self-reported measure of a participants' use of provided KPIs. The scale is from 0 (=no KPI used) to the respective maximum of the relevant group (e.g., 2 in the " 2 KPI" group).

Responsibility (CV): Our responsibility measure is drawn from Whyte's (1991) approach and assessed using the following question: "To what extent do you feel responsible for the future development of the product division that you selected?" ( $0=$ not at all; $10=$ very much).

Age (CV): We asked for the participants' age in years. 
Table 2 Summary statistics

\begin{tabular}{|c|c|c|c|c|}
\hline & \multicolumn{4}{|c|}{ Information load } \\
\hline & $2 \mathrm{KPI}$ & $4 \mathrm{KPI}$ & $8 \mathrm{KPI}$ & $12 \mathrm{KPI}$ \\
\hline \multicolumn{5}{|l|}{ Type of feedback } \\
\hline \multicolumn{5}{|l|}{ Positive feedback } \\
\hline Mean & 6.600 & 8.296 & 11.361 & 11.750 \\
\hline $\begin{array}{l}\text { Standard devia- } \\
\text { tion }\end{array}$ & 6.210 & 5.830 & 5.015 & 4.983 \\
\hline Median & 5 & 10 & 12 & 12 \\
\hline Percentile 25 & 0 & 5 & 6 & 8 \\
\hline Percentile 75 & 15 & 15 & 15 & 15 \\
\hline \multicolumn{5}{|l|}{ Negative feedback } \\
\hline Mean & 13.815 & 11.286 & 11.045 & 12.524 \\
\hline $\begin{array}{l}\text { Standard devia- } \\
\text { tion }\end{array}$ & 5.204 & 5.062 & 4.695 & 5.501 \\
\hline Median & 15 & 10 & 10 & 11 \\
\hline Percentile 25 & 10 & 8 & 7 & 10 \\
\hline Percentile 75 & 20 & 15 & 15 & 15 \\
\hline
\end{tabular}

Gender (CV): We asked for the participants' gender. We coded 1 for female, 0 for male.

\section{Results}

\subsection{Manipulation checks and descriptive statistics}

We first tested for successful randomization of the participants across cells. The Kruskal-Wallis $\mathrm{H}$ test indicates successful randomization across cells $\left(\mathrm{H}(3)^{2}=0.233, \mathrm{p}>0.10\right)$. Because all the participants are responsible for the initial decision, we control for whether the participants feel responsible.

In relation to escalation of commitment, our results align with self-justification theory which predicts the participants who report feeling responsible for their initial decision show a stronger tendency to justify their behavior than participants who do not feel such a responsibility. Following Whyte (1991), we analyze the influence of the participants' reported feelings of responsibility for the first decision. The mean level of responsibility is 7.78 (S.D. = 2.229) on an 11-point Likert scale. We use the one-sample t test to investigate whether the mean deviates from the scale medium of $5(\mathrm{t}(200)=17.262$, $\mathrm{p}<0.001$ ), indicating that the participants felt a high level of responsibility.

\footnotetext{
${ }^{2}$ We report the results following APA (American Psychological Association) style, i.e., $H(3)=0.233$ describes that a Kruskal-Wallis $\mathrm{H}$ test with 3 degrees of freedom $(\mathrm{df}=\mathrm{n}-1)$ has a chi-square value of 0.233 , which is not significant $(\mathrm{p}>0.10)$.
} 
We also check whether our negative-feedback condition indicates a higher level of responsibility compared to the positive-feedback condition. A comparison of means shows that, when facing negative feedback, participants feel more responsible $(\mathrm{M}=8.16$, S.D. $=1.904)$ than they do when facing positive feedback $(\mathrm{M}=7.41$, S.D. $=2.557 ; \mathrm{t}(200)=2.369, \mathrm{p}<0.05)$. We verified this result using the Mann-Whitney $U$ test $(U=4129, \mathrm{p}=0.023, \mathrm{r}=0.16)$ and the Kruskal-Wallis $\mathrm{H}$ test $(\mathrm{H}(1)=5.151, \mathrm{p}<0.05)$. Both tests indicated a significant difference. Additionally, we check whether responsibility differs between information load conditions. We use the Kruskal-Wallis $\mathrm{H}$ test and find no significant difference $(\mathrm{H}(3)=0.980$, $\mathrm{p}=0.806$ ).

In relation to information load, we checked whether the participants used the KPIs provided. We find that the participants used the additional KPIs provided $(\beta=0.486, \mathrm{p}<0.001)$. The Kruskal-Wallis $\mathrm{H}$ test shows that we find different uses of KPIs across cells $(\mathrm{H}(8)=60.290, \mathrm{p}<0.001)$.

In relation to investment behavior, Table 2 shows that, in the negative-feedback condition, the allocation of resources to the initially chosen business division (escalation tendency) decreases from the 2 KPI condition over the 4-KPI condition to the 8 -KPI condition and then rebounds in the 12-KPI condition. In the positive-feedback condition, the allocation of resources to the initially chosen business division continuously increases with the number of KPIs over the four conditions. Table 3 provides the results of the independent samples test, which indicate different behavior in negative and positive feedback situations.

\subsection{Effect of information load in a negative feedback situation}

We checked for the theoretical mechanism regarding the effect of self-justification on the allocation of resources, i.e., the escalation of commitment. When we analyze whether the negative or positive feedback that the participants receive after their initial funding decision influences the amount of resources that they allocate in the second part of the experiment we find that the participants who are given negative accounting information (negative feedback $\mathrm{M}=12.22$ ) allocate more resources than those who are given positive accounting information (positive feedback $M=10.70$; $\mathrm{t}(201)=1.915, \mathrm{p}<0.05, \mathrm{~d}=1.52)$, in line with existing research (Schulz and

Table 3 Independent samples test

\begin{tabular}{llllll}
\hline Type of feedback & $\mathrm{t}$ & $\mathrm{df}$ & Sig. (2-tailed) & Mean difference & $\begin{array}{c}\text { Std. error } \\
\text { difference }\end{array}$ \\
\hline $\begin{array}{l}\text { Allocation of resources (negative + pos- } \\
\text { itive feedback) }\end{array}$ & -0.428 & 81.989 & 0.670 & -0.497 & 1.161 \\
$\begin{array}{l}\text { Allocation of resources (negative } \\
\text { feedback) }\end{array}$ & 1.935 & 47 & 0.059 & 2.769 & 1.431 \\
$\begin{array}{l}\text { Allocation of resources (positive } \\
\text { feedback) }\end{array}$ & -3.124 & 54 & 0.003 & -4.761 & 1.524 \\
\hline
\end{tabular}

This table reports the results for independent t-tests. We checked equality of variances with Levene's test and report the corresponding results (with corrected df). Allocation of Resources describes the amount of resources participants provide to the chosen investment project (ranges from 0 to 20) 
Table 4 ANOVA results

\begin{tabular}{llllll}
\hline Source & $\begin{array}{l}\text { Type III sum of } \\
\text { squares }\end{array}$ & df & Mean Square & F & Sig \\
\hline Information load & 154.056 & 3 & 51.352 & 1.824 & 0.144 \\
$\begin{array}{l}\text { Type of feedback } \\
\text { Information load } \times \text { type }\end{array}$ & 343.838 & 1 & 343.838 & 12.216 & 0.001 \\
$\quad$ of feedback & 397.014 & 3 & 132.338 & 4.702 & 0.003 \\
Error & 5432.466 & 193 & 28.147 & & \\
\hline
\end{tabular}

This table reports the ANOVA for the effect of information load and type of feedback on allocation of resources. Information Load describes the number of KPIs provided to participants (ranges from 2 to 12 in the four treatment conditions ( $2 \mathrm{KPI}, 4 \mathrm{KPI}, 8 \mathrm{KPI}, 12 \mathrm{KPI})$ ). Type of Feedback is coded 0 in the positive-feedback condition and 1 in the negative-feedback condition

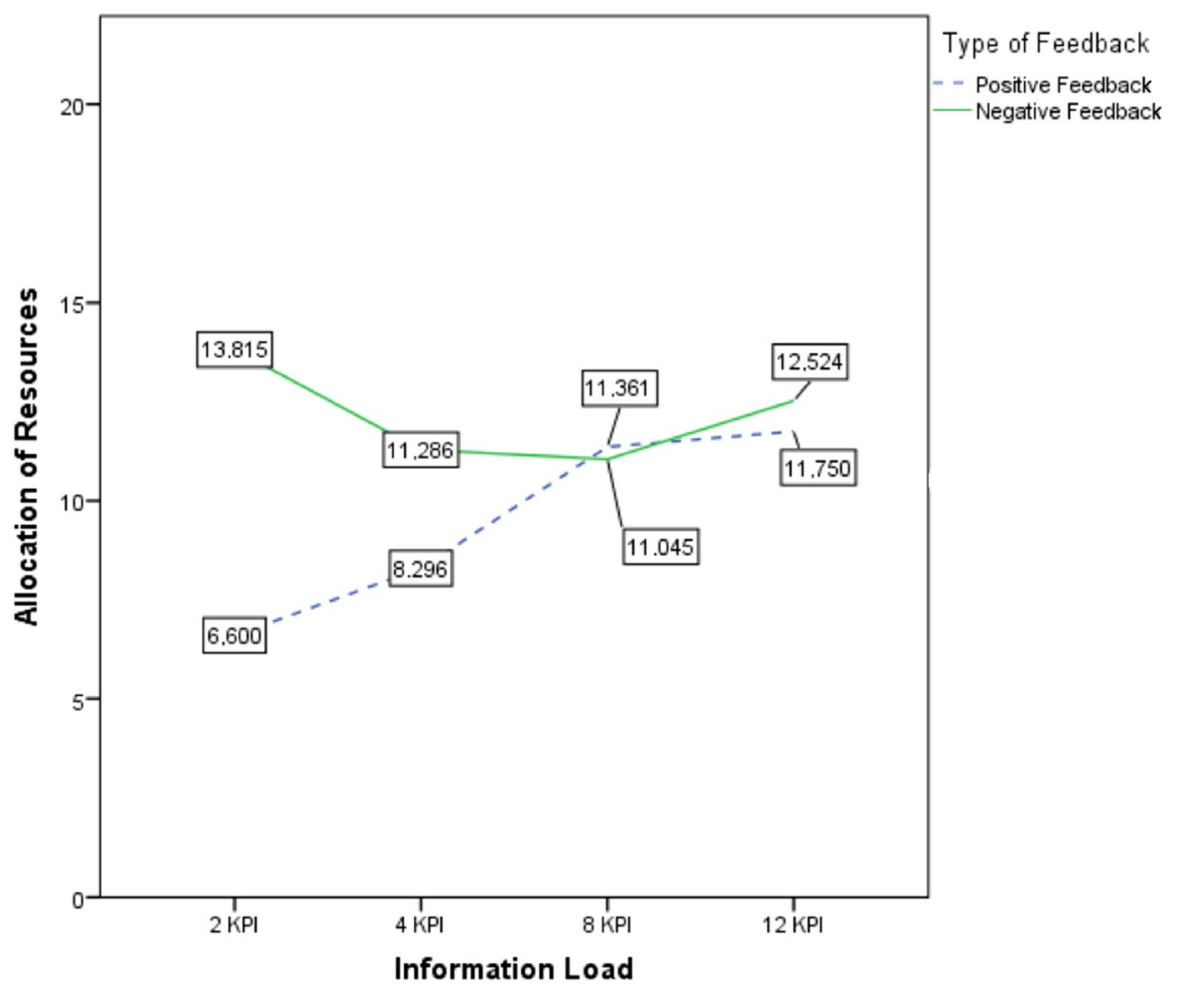

Fig. 1 Effect of different information load levels under negative and positive feedback

Cheng 2002; Sleesman et al. 2012; Staw 1976). We verified this result using the Mann-Whitney $U$ test $(U=3922, \mathrm{p}<0.01, \mathrm{r}=0.20)$ and the Kruskal-Wallis $\mathrm{H}$ test $(\mathrm{H}(1)=7.633, \mathrm{p}<0.01)$. Both tests indicate a significant difference.

H1 predicts that, when facing negative feedback, increasing the information provided reduces the escalation of commitment up to a certain point. 


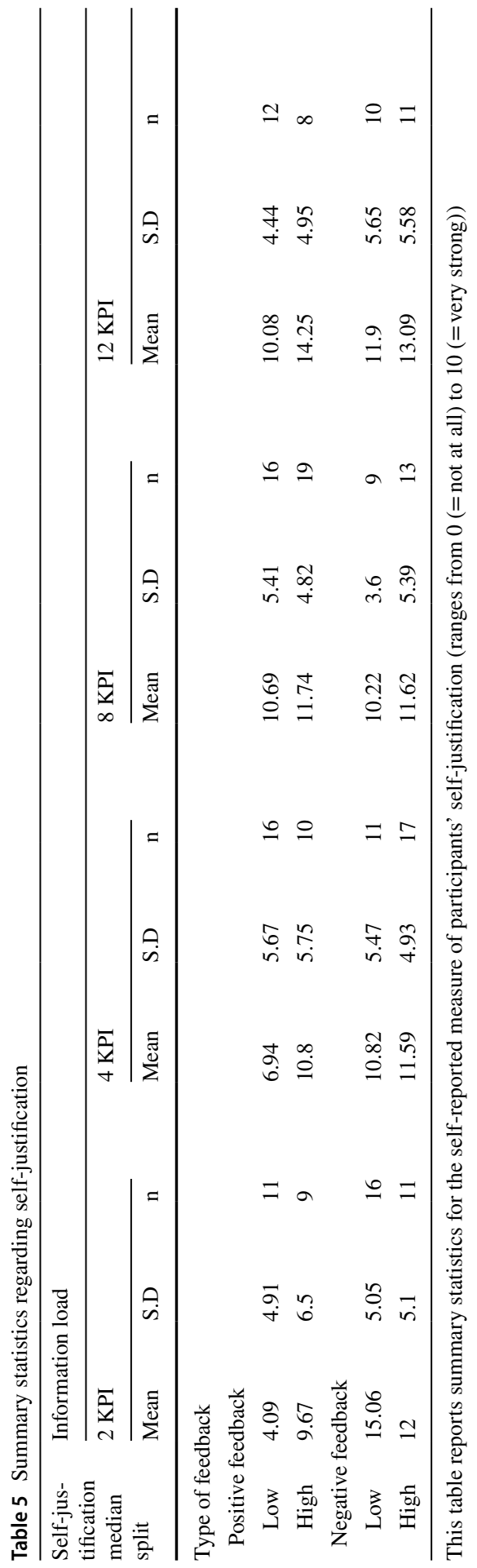




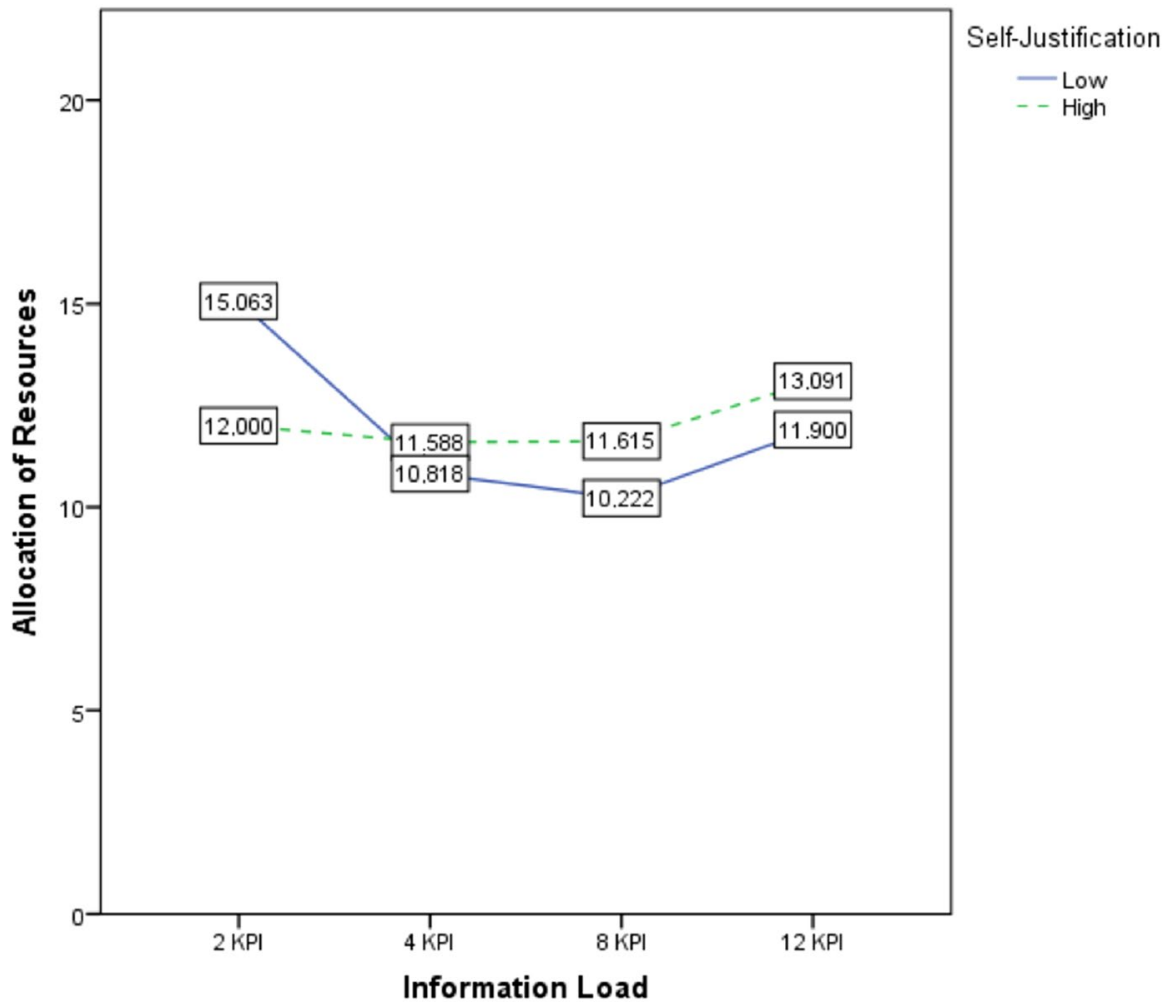

Fig. 2 Allocation of resources with low and high self-justification in the negative-feedback condition

Planned polynomial contrasts indicate a significant quadratic relationship between information load and escalation behavior (contrast estimate $=2.004$ vs. hypothesized value $=0$, S.D. $=1.042, \mathrm{p}=0.058)$.

Drawing on Shields (1983), we calculated a regression to check for the U-shaped relationship. An ordinary least squares (OLS) regression with allocation of resources as the dependent variable and squared KPIs as the independent variable shows a significant U-shaped relationship $(\beta=-0.112, \mathrm{p}<0.01, \mathrm{~F}=3.314, \mathrm{p}<0.10)$. We also checked whether other functional forms of the relationship between allocation of resources and information load might represent the relationship. Neither a linear OLS regression $(F=0.476, p=0.492)$ nor a cubic regression $(F=1.594, p=0.196)$ revealed a significant result. Thus, $\mathrm{H} 1$ is supported.

We conduct analysis of variance (ANOVA) to test for an interaction effect between the type of feedback and the information load. A 2 (consequence of initial decision: positive feedback/positive accounting information vs. negative feedback/ negative accounting information) $\times 4$ (information load: 2, 4, 8, 12 KPIs) ANOVA reveals a positive and significant interaction between the type of feedback and the information load (Table 4). Figure 1 shows the results. 


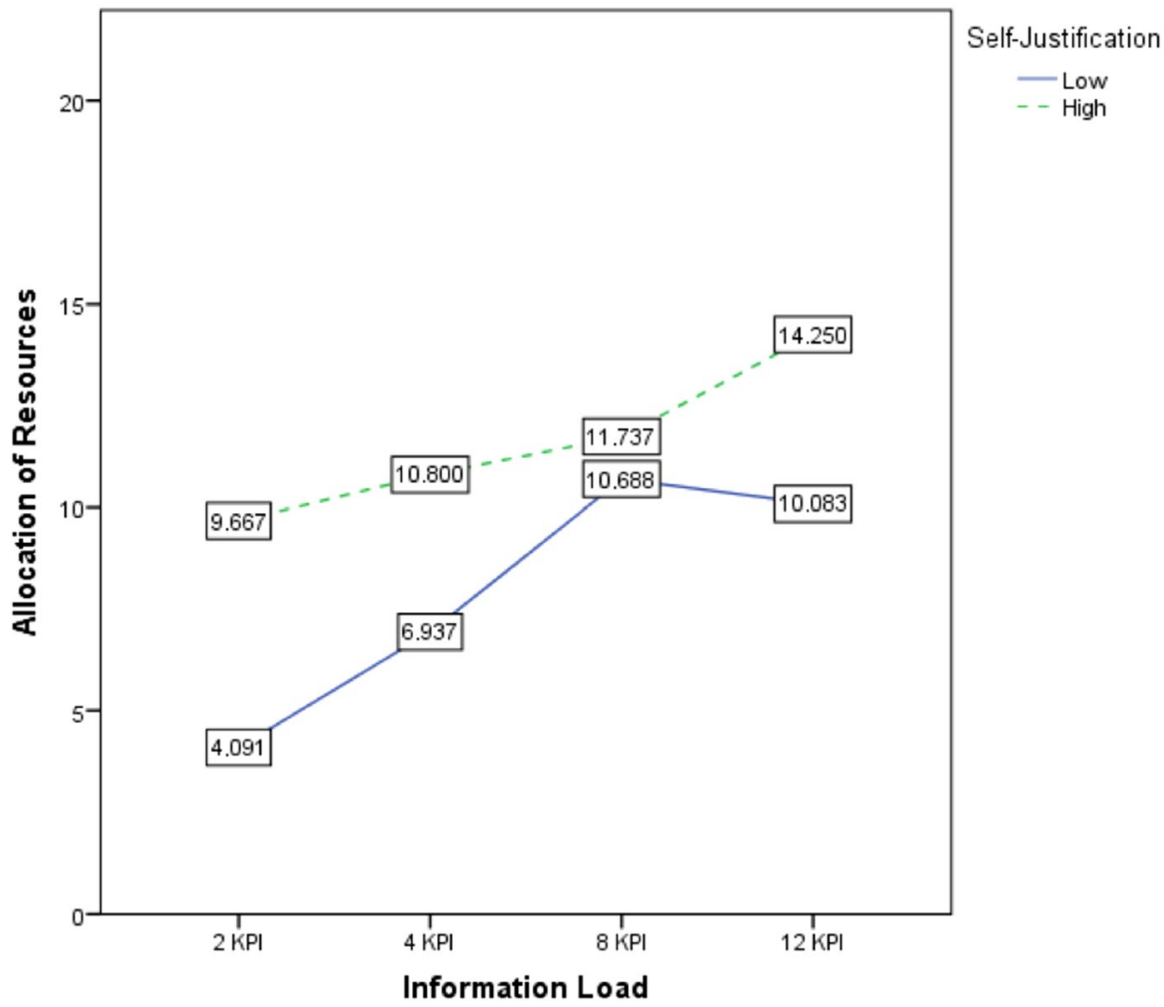

Fig. 3 Allocation of resources with low and high self-justification in the positive-feedback condition

Our findings indicate that, in the negative-feedback condition with 2 , 4, and 8 KPIs, more information reduces the escalation tendency. If even more information is provided (12 KPI condition), we find that the escalation tendency increases again.

Research question RQ1 asks how information load and self-justification interact in influencing escalation of commitment when facing negative feedback. We expect that nonlinearities are involved in the interaction between information load and selfjustification. RQ1 focuses on the negative-feedback condition as we do not expect self-justification to play a relevant role in the positive-feedback condition. Nonetheless, we include the positive-feedback condition in the following analysis for reasons of comparison.

We use a median split discussed in the recent literature (e.g., Iacobucci et al. 2015). We split the sample into two approximately equal groups (low/high selfjustification) and add the median participants to the lower self-justification group (Iacobucci et al. 2015). Table 5 shows summary statistics regarding the two groups of self-justification. It is striking that we observe a broad range of values for selfjustification in the positive-feedback condition. 
Figures 2 and 3 show the allocation of resources with low and high self-justification of participants under different information load conditions for the negativefeedback and the positive-feedback condition respectively. Our results indicate that the type of feedback affects self-justification. In the positive-feedback condition, we find increasing levels of allocation of resources in the high-self-justification group when information load increases. We check for differences between the low and high self-justification groups in the negative-feedback condition using the Mann-Whitney $U$ test $(U=1149.5, p=0.737)$ and the Kruskal-Wallis $H$ test $(H(1)=0.113$, $\mathrm{p}=0.737$ ). Both tests indicate that there is no significant difference between groups in the negative-feedback condition. Moreover, we check for differences between the low and high self-justification groups in the positive-feedback condition using the Mann-Whitney U test $(\mathrm{U}=847.5, \mathrm{p}<0.01, \mathrm{r}=0.29)$ and the Kruskal-Wallis $\mathrm{H}$ test $(\mathrm{H}(1)=5.769, \mathrm{p}<0.01)$. Both tests indicate a significant difference between groups.

We used a moderated mediation model drawing from Hayes (2015) to calculate possible interactions between information load and self-justification. We used information load (i.e., KPI) as the independent variable, self-justification as the mediator, allocation of resources as the dependent variable and type of feedback as the moderator of the three relationships in the mediation model.

Table 6 shows the results of the moderated mediation model. We find that self-justification is affected by type of feedback, as expected. Furthermore, although we do not find a direct effect of information load on self-justification, we find a negative and significant interaction between information load and selfjustification. In a detailed conditional effects analysis of the focal predictor at values of the moderator, we find that this effect occurs in negative-feedback cases only $(\mathrm{w}=-0.139, \mathrm{p}<0.05,95 \% \mathrm{CI}=[-0.258 ;-0.020])$, while there is no effect in positive feedback cases. This indicates that information load reduces self-justification in some manner.

In relation to the additive effect of both variables on allocation of resources, we find that both information load and self-justification increase allocation of resources next to the effect of negative feedback. Our results reveal two significant interactions. First, we find a negative moderation of the type of feedback on the relationship between information load and allocation of resources, indicating that negative feedback reduces the participants' tendency to invest more with increasing information load. Second, our results show that there is a negative and significant moderation of type of feedback on the relationship between selfjustification and allocation of resources, indicating that, in a model with information load, self-justification has no consistent increasing effect on allocation of resources in escalation situations.

\subsection{Effect of information load in a positive feedback situation}

Hypothesis $\mathrm{H} 2$ predicts that, with the participant facing positive feedback, increasing information load positively affects the resources allocated to a promising course of action up to a certain point and decreases from that point on. The ANOVA in Table 4 has already shown that there is a significant interaction effect 


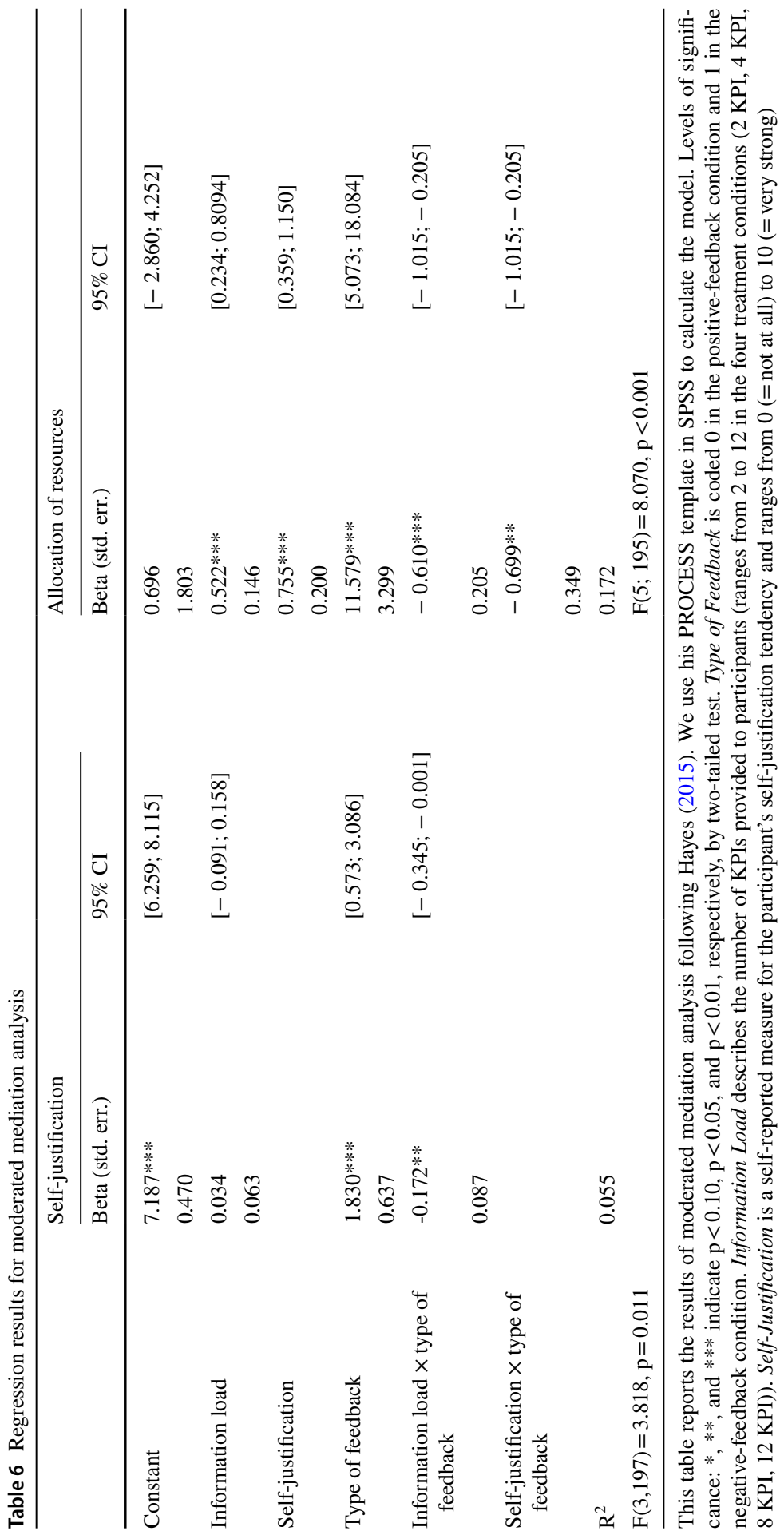


between the type of feedback and the information load. Also, in the previous section, we discussed the interaction of information overload and self-justification also for the positive feedback situation. Those outcomes did not examine the functional form of the relationship between information overload and allocation of resources in the positive feedback situation. For that analysis we undertook a procedure similar to that of Shields (1983). We calculated a quadratic OLS regression with allocation of resources as the dependent variable and both a squared information load and a linear information load (i.e., KPI) as independent variables. The OLS regression is significant $(F=7.163, p<0.01)$, but we find that the quadratic term is not significant $(\beta=0.066, \mathrm{p}=0.203)$, while the linear term is significant $(\beta=0.889, \mathrm{p}<0.05)$. Hence, $\mathrm{H} 2$ is not supported. Figure 1 in the previous section already suggested this finding.

In the case of positive feedback, we find that increasing the information load leads to higher investments $\left(\mathrm{F}(1,101)=12.601, \mathrm{p}<0.001, \mathrm{R}^{2}=0.102\right.$, std. $\beta=0.333$, $\mathrm{p}<0.05)$.

An unexpected result was that the relationship is not quadratic but linear. To check for a linear relationship, we calculate an OLS regression with allocation of resources as the dependent variable and a linear information load as the independent variable. This OLS regression is highly significant $(\mathrm{F}=12.601, \mathrm{p}<0.01)$, and the coefficient is positive and significant $(\beta=0.547, \mathrm{p}<0.01)$.

\section{Discussion and conclusions}

Our main analysis synthesizes existing escalation research (e.g., Sleesman et al. 2012, 2018) with information overload (e.g., Eppler and Mengis 2004, Roetzel 2019) and shows that, when decision makers face negative feedback, a higher information load mitigates the escalation tendency up to a certain point. Beyond this point, more information increases the escalation tendency. The finding of a significant interaction between the type of feedback and the information load extends our knowledge about the role of information processing in decision making in escalation situations. Furthermore, we find that the type of feedback affects self-justification, and we find a negative and significant interaction between information load and selfjustification in negative-feedback cases.

Our study contributes to a major stream of research on escalation of commitment research (e.g., Sleesman et al. 2012, 2018) by showing that the quantity of provided information is relevant in both escalation-related decision making with negative feedback and in the positive-feedback condition. This fills a gap in existing research which has an omission regarding the role of information load in the decision-making process. This gap in earlier studies has been the result of their concentration on information search and selection (e.g., Schultze et al. 2012), as well as on distraction by incoherent information (e.g., Denison 2009; Schultze et al. 2012), and on ignoring information (Conlon and Parks 1987; Staw 1981). The main finding of our study indicates that existing escalation of commitment research might be 
biased by the use of different levels of information load without checking for information (over-)load issues. In particular, studies examining the escalation of commitment with a high quantity of information provided might be viewed in a different light. Based on our findings we suggest that further studies should check for both self-justification and information load when utilizing high levels of information load in experiments investigating the escalation of commitment (e.g., Kadous and Sedor 2004; Kanodia et al. 1989; Schulz and Cheng 2002).

In positive-feedback cases we do not find the expected inverse U-shaped relationship. Instead we find that a higher information load encourages decision makers to continue the promising course of action. A possible explanation for this finding could be that the cognitive load induced by confirmatory information might be lower than the cognitive load induced by information that contradicts the advantageousness of the initial investment. Consequently, the participants might not be in an overload condition with positive feedback consisting of 12 KPIs. This could be investigated by replicating our study with a widened range of the number of KPIs.

Our results have implications for the design of effective management information systems and management controls regarding continuation or discontinuation of existing investment projects. Our findings indicate that, within the range of number of KPIs investigated, more comprehensive management reports are beneficial in positive investment courses. Additional positive information encourages individuals to invest more in a good performing course of action. In this case, we find no indications of information overload on decision-making performance. Management controls that involve a higher information load seem to be unproblematic from that perspective.

In contrast, when an investment performs poorly, additional information might reduce decision-making performance considerably from a certain level on. Hence, in negative-feedback situations, management reports should not be too extensive but restrict the use of KPIs to the medium range (in our study: 4 to 8 KPIs). When designing management controls and other mechanisms to de-escalate, the information load entailed by these mechanisms should not be too high. In the case that managers selfselect reporting elements, restrictive measures should be taken to prevent them from overloading themselves with KPIs. Ideally, the information load of reports should vary between positive- and negative-feedback situations, e.g., by using different report schemes. If this kind of tailoring to the situation is not possible or too costly, a tradeoff must be made between using too many KPIs in negative-feedback situations and not enough KPIs in positive-feedback situations. In the negative-feedback condition, the level of self-justification does not seem to play a major role for the allocation of resources; thus, our findings suggest, that the focus should be more on optimizing information load.

The results of this study have some limitations and suggest several avenues for future research. First, the theoretical model that we use to analyze the escalation of commitment and information load can also be applied to other escalation situations. Our finding that information load suppresses the escalating commitment allows us to view previous studies of the psychological mechanisms underlying the phenomenon of escalation in a different light. While self-justification is one mechanism 
explaining the escalation of commitment, there are other theoretical approaches, such as prospect theory (Whyte 1991). Further research should explore other mechanisms of escalation of commitment, e.g., those drawn from prospect theory. Second, we used simple decision scenarios and samples that exclusively consisted of students. While studies have shown students to be justifiable surrogates for managers in decision making (Cheng et al. 2003; Clinton 1999; Elliot et al. 2007), we would expect that more experienced decision makers would be able to process a larger number of KPIs and thus that the optimal number of KPIs is larger than that for students. At the same time, we would not expect the U-shaped effect to be altered qualitatively. Further research might replicate and extend our experiment with more experienced participants, such as project managers, or might conduct field studies.

Third, in line with the extant literature (e.g., Chewning and Harrell 1990; Simnet 1996), we do not address the decision usefulness of additional information. For example, the first two KPIs provided are absolute KPIs, and the third and the fourth KPI are relative KPIs that might be perceived differently by participants. Moreover, we did not use a process measure to identify how participants concentrate on the additional information and to assess their cognitive load. In our setting, eye tracking could be used to indicate content use and cognitive load. We encourage further research to use such process measures. To avoid possible effects of different KPI content, we could have randomized the assignment of different KPIs to the 2, 4, 8 and 12 KPI conditions by accepting the rise of content-related issues instead (e.g., in the "2 KPI" condition, participants might receive CASALES (current assets/ sales) and WCSLS (working capital/sales) instead of earnings and sales). We do not randomize our KPIs provided to be comparable to the experiment of Simnet (1990). Consequently, we cannot exclude a potential bias depending on the KPIs assigned to the conditions, even if all KPIs point in the same direction.

Fourth and related to the previous limitation, we used correlated information in our experiments. Future studies should investigate the extent to which the correlation or noncorrelation of information might reduce or intensify bias in escalating situations. Finally, we used retrospective KPIs. Previous research has indicated that decision makers evaluate retrospective and prospective information differently (e.g., Conlon and Parks 1987; Schultze et al. 2012). We argue that testing the effect of prospective information on decision-makers' choices is a promising avenue for future research.

Acknowledgements Open Access funding provided by Projekt DEAL.

Open Access This article is licensed under a Creative Commons Attribution 4.0 International License, which permits use, sharing, adaptation, distribution and reproduction in any medium or format, as long as you give appropriate credit to the original author(s) and the source, provide a link to the Creative Commons licence, and indicate if changes were made. The images or other third party material in this article are included in the article's Creative Commons licence, unless indicated otherwise in a credit line to the material. If material is not included in the article's Creative Commons licence and your intended use is not permitted by statutory regulation or exceeds the permitted use, you will need to obtain permission directly from the copyright holder. To view a copy of this licence, visit http://creativecommons.org/licen ses/by/4.0/. 


\section{Appendix A}

See Table 7.

Table 7 Group design

\begin{tabular}{|c|c|c|c|c|}
\hline Information load & $2 \mathrm{KPI}$ & $4 \mathrm{KPI}$ & $8 \mathrm{KPI}$ & $12 \mathrm{KPI}$ \\
\hline EARNINGS & $\mathrm{X}$ & $X$ & $X$ & $\mathrm{X}$ \\
\hline SALES & $\mathrm{X}$ & $\mathrm{X}$ & $\mathrm{X}$ & $\mathrm{X}$ \\
\hline EBTA (earnings before taxes and amortization) & & $X$ & $\mathrm{X}$ & $\mathrm{X}$ \\
\hline EBSA (earnings before interest and tax/sales) & & $\mathrm{X}$ & $\mathrm{X}$ & $\mathrm{X}$ \\
\hline EATA (earnings after interest and tax/total assets) & & & $\mathrm{X}$ & $\mathrm{X}$ \\
\hline SLSNTWT (sales/shareholder equity) & & & $\mathrm{X}$ & $X$ \\
\hline SLSTA (sales/total assets) & & & $\mathrm{X}$ & $\mathrm{X}$ \\
\hline SLSAR (sales/accounts receivable) & & & $\mathrm{X}$ & $\mathrm{X}$ \\
\hline CASALES (current assets/sales) & & & & $\mathrm{X}$ \\
\hline TIE (earnings before interest and tax/interest) & & & & $X$ \\
\hline EASF (earnings after interest and tax/shareholder equity) & & & & $\mathrm{X}$ \\
\hline WCSLS (working capital/sales) & & & & $\mathrm{X}$ \\
\hline
\end{tabular}

\section{Appendix B: Experimental procedure}

\section{Dear participants,}

We appreciate very much that you are supporting our study!

The study is an economic case study. Based on authentic economic situations, an investment problem is simulated. The name of the company in this study ("Adam \& Smith, Inc.") is fictitious. The simulation is designed such that it can also be worked by persons without previous knowledge of the presented case.

Over the course of the study, you will make investment decisions. Your decisions affect the development and the balance-sheets of "Adam \& Smith".

To improve the comparability, all amounts of money (e.g., on the balance sheets) are given in euros.

All of the information given by you is anonymous; no information is collected that could allow for identifying you personally.

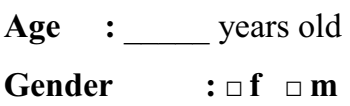

Subject of studies

Study semester 
This exercise is concerned with managerial decision making. You are asked to play the role of the Financial Vice President of "Adams and Smith, Inc.". Your task is to make a series of decisions concerning the investment of organizational funds.

You will be asked to make a series of funding decisions in the case. There is ample information contained in the case to make a high-quality decision. After the decision, you will receive feedback about the degree of success or failure of your decision.

(Only when the experiment is conducted via computer/online): This feedback is based on a complex computer simulation of the situation described in the case and considers a wide variety of information: sales and earnings figures; the economic conditions prevailing at the time; competition in the industry; and relationships between the principal actors in the case, to name a few.

Successful managerial decision making requires knowing what information to attend to and how to interpret it correctly.

In 2009, the profitability of Adam and Smith, Inc., is decreasing. The company's Board of Directors has concluded that $€ 10$ million of additional R\&D funds should be made available to its major operating divisions; however, for now, the extra funding should be invested in only one of the corporation's two largest divisions. "Consumer Products" or "Industrial Products".

The "Consumer Products" division focuses on private customers (e.g., fridgefreezer and other white goods). The products are known for their high-quality level and ease of operation. The "Industrial Products" division has a strong competitive position in fast food equipment and focuses on large equipment for commercial kitchens.

You are asked to make the financial investment decision based on the potential benefit that $R \& D$ funding would have on the following accounting information of the divisions.

For example: 4 KPI Case.

\begin{tabular}{|c|c|c|c|c|c|c|c|c|c|}
\hline \multicolumn{5}{|c|}{ Consumer products } & \multicolumn{5}{|c|}{ Industrial products } \\
\hline \multirow[t]{2}{*}{$\begin{array}{l}\text { Fiscal } \\
\text { year }\end{array}$} & Sales & $\begin{array}{l}\text { Earn- } \\
\text { ings }\end{array}$ & EBITA & $\begin{array}{l}\text { EBITA/ } \\
\text { Sales }\end{array}$ & $\begin{array}{l}\text { Fiscal } \\
\text { year }\end{array}$ & Sales & $\begin{array}{l}\text { Earn- } \\
\text { ings }\end{array}$ & EBITA & $\begin{array}{l}\text { EBITA/ } \\
\text { Sales }\end{array}$ \\
\hline & $\begin{array}{l}\text { [in Mio } \\
€]\end{array}$ & $\begin{array}{l}\text { [in Mio } \\
€]\end{array}$ & $\begin{array}{l}\text { [in Mio } \\
€]\end{array}$ & & & $\begin{array}{l}\text { [in Mio } \\
€]\end{array}$ & $\begin{array}{l}\text { [in Mio } \\
€]\end{array}$ & $\begin{array}{l}\text { [in Mio } \\
€]\end{array}$ & \\
\hline 2000 & 624.00 & 14.42 & 17.304 & 0.028 & 2000 & 670.00 & 15.31 & 18.372 & 0.027 \\
\hline 2001 & 626.00 & 10.27 & 12.324 & 0.020 & 2001 & 663.00 & 10.92 & 13.104 & 0.020 \\
\hline 2002 & 649.00 & 8.65 & 10.380 & 0.016 & 2002 & 689.00 & 11.06 & 13.272 & 0.019 \\
\hline 2003 & 681.00 & 8.46 & 10.152 & 0.015 & 2003 & 711.00 & 10.44 & 12.528 & 0.018 \\
\hline 2004 & 674.00 & 4.19 & 5.028 & 0.007 & 2004 & 724.00 & 9.04 & 10.848 & 0.015 \\
\hline 2005 & 702.00 & 5.35 & 6.420 & 0.009 & 2005 & 735.00 & 6.38 & 7.656 & 0.010 \\
\hline 2006 & 717.00 & 3.92 & 4.704 & 0.007 & 2006 & 748.00 & 5.42 & 6.504 & 0.009 \\
\hline 2007 & 741.00 & 4.66 & 5.592 & 0.008 & 2007 & 756.00 & 3.09 & 3.708 & 0.005 \\
\hline 2008 & 765.00 & 2.48 & 2.976 & 0.004 & 2008 & 784.00 & 3.26 & 3.912 & 0.005 \\
\hline 2009 & 770.00 & -0.12 & -0.144 & 0.000 & 2009 & 788.00 & -0.81 & -0.972 & -0.001 \\
\hline 2010 & 769.00 & -0.63 & -0.756 & -0.001 & 2010 & 791.00 & -0.80 & -0.960 & -0.001 \\
\hline
\end{tabular}


YOU are asked to allocate $€ 10$ million of $R \& D$ funding to promote one of the two divisions, which can use the funding at will.

Which division receives the $€ 10$ million of $R \& D$ funding?

Consumer Products $\square$

Industrial Products $\square$

Kindly let us know more about your decision:

To what extent do you feel responsible for the future development of the division of products that you selected?

$\begin{array}{lcccccccccc}\square & \square & \square & \square & \square & \square & \square & \square & \square & \square & \square \\ \mathbf{0} & \mathbf{1} & \mathbf{2} & \mathbf{3} & \mathbf{4} & \mathbf{5} & \mathbf{6} & \mathbf{7} & \mathbf{8} & \mathbf{9} & \mathbf{1 0} \\ \text { not at all } & & & & & & & & & \end{array}$

To what extent do you feel the need to justify your initial decision?

$\begin{array}{lcccccccccc}\square & \square & \square & \square & \square & \square & \square & \square & \square & \square & \square \\ \mathbf{0} & \mathbf{1} & \mathbf{2} & \mathbf{3} & \mathbf{4} & \mathbf{5} & \mathbf{6} & \mathbf{7} & \mathbf{8} & \mathbf{9} & \mathbf{1 0} \\ \text { not at all } & & & & & & & & & \end{array}$

Now, the second part begins:

Please open the envelope labeled "Industrial Products" when you have allocated $€ 10$ million to that division.

Please open the envelope labeled "Consumer Products" when you have allocated $€ 10$ million to that division.

Look at the following accounting information.

(Here, participants obtain positive/negative feedback about their initial decisions, e.g., $4 \mathrm{KPI})$. 
Participant chose "Consumer Products" and faced negative feedback

\begin{tabular}{|c|c|c|c|c|c|c|c|c|c|}
\hline \multicolumn{5}{|c|}{ Consumer products } & \multicolumn{5}{|c|}{ Industrial products } \\
\hline \multirow[t]{2}{*}{$\begin{array}{l}\text { Fiscal } \\
\text { year }\end{array}$} & Sales & $\begin{array}{l}\text { Earn- } \\
\text { ings }\end{array}$ & EBITA & $\begin{array}{l}\text { EBITA/ } \\
\text { Sales }\end{array}$ & $\begin{array}{l}\text { Fiscal } \\
\text { year }\end{array}$ & Sales & $\begin{array}{l}\text { Earn- } \\
\text { ings }\end{array}$ & EBITA & $\begin{array}{l}\text { EBITA/ } \\
\text { Sales }\end{array}$ \\
\hline & $\begin{array}{l}\text { [in Mio } \\
€]\end{array}$ & $\begin{array}{l}\text { [in Mio } \\
€]\end{array}$ & $\begin{array}{l}\text { [in Mio } \\
€]\end{array}$ & & & $\begin{array}{l}\text { [in Mio } \\
€]\end{array}$ & $\begin{array}{l}\text { [in Mio } \\
€]\end{array}$ & $\begin{array}{l}\text { [in Mio } \\
€]\end{array}$ & \\
\hline 2011 & 771 & -1.12 & -1.344 & -0.002 & 2011 & 818 & 0.02 & 0.024 & 0.000 \\
\hline 2012 & 774 & -1.96 & -2.352 & -0.003 & 2012 & 829 & -0.09 & -0.108 & 0.000 \\
\hline 2013 & 762 & -3.87 & -4.644 & -0.006 & 2013 & 827 & -0.23 & -0.276 & 0.000 \\
\hline 2014 & 778 & -3.83 & -4.596 & -0.006 & 2014 & 846 & 0.06 & 0.072 & 0.000 \\
\hline $\begin{array}{l}2015 \\
\text { (est.) }\end{array}$ & 783 & -4.16 & -4.992 & -0.006 & $\begin{array}{l}2015 \\
\text { (est.) }\end{array}$ & 910 & 1.28 & 1.536 & 0.002 \\
\hline
\end{tabular}

EBITA earnings before interest, taxes and, amortization

Participant chose "Industrial Products" and faced negative feedback

\begin{tabular}{|c|c|c|c|c|c|c|c|c|c|}
\hline \multicolumn{5}{|c|}{ Consumer products } & \multicolumn{5}{|c|}{ Industrial products } \\
\hline \multirow[t]{2}{*}{$\begin{array}{l}\text { Fiscal } \\
\text { year }\end{array}$} & Sales & $\begin{array}{l}\text { Earn- } \\
\text { ings }\end{array}$ & EBITA & $\begin{array}{l}\text { EBITA/ } \\
\text { sales }\end{array}$ & $\begin{array}{l}\text { Fiscal } \\
\text { year }\end{array}$ & Sales & $\begin{array}{l}\text { Earn- } \\
\text { ings }\end{array}$ & EBITA & $\begin{array}{l}\text { EBITA/ } \\
\text { sales }\end{array}$ \\
\hline & $\begin{array}{l}\text { [in Mio } \\
€]\end{array}$ & $\begin{array}{l}\text { [in Mio } \\
€]\end{array}$ & $\begin{array}{l}\text { [in Mio } \\
€]\end{array}$ & & & $\begin{array}{l}\text { [in Mio } \\
€]\end{array}$ & $\begin{array}{l}\text { [in Mio } \\
€]\end{array}$ & $\begin{array}{l}\text { [in Mio } \\
€]\end{array}$ & \\
\hline 2011 & 818 & 0.02 & 0.024 & 0.000 & 2011 & 771 & -1.12 & -1.344 & -0.002 \\
\hline 2012 & 829 & -0.09 & -0.108 & 0.000 & 2012 & 774 & -1.96 & -2.352 & -0.003 \\
\hline 2013 & 827 & -0.23 & -0.276 & 0.000 & 2013 & 762 & -3.87 & -4.644 & -0.006 \\
\hline 2014 & 846 & 0.06 & 0.072 & 0.000 & 2014 & 778 & -3.83 & -4.596 & -0.006 \\
\hline $\begin{array}{l}2015 \\
\text { (est.) }\end{array}$ & 910 & 1.28 & 1.536 & 0.002 & $\begin{array}{l}2015 \\
\text { (est.) }\end{array}$ & 783 & -4.16 & -4.992 & -0.006 \\
\hline
\end{tabular}

EBITA earnings before interest, taxes and, amortization

Participant chose "Consumer Products" and faced positive feedback

\begin{tabular}{|c|c|c|c|c|c|c|c|c|c|}
\hline \multicolumn{5}{|c|}{ Consumer products } & \multicolumn{5}{|c|}{ Industrial products } \\
\hline \multirow[t]{2}{*}{$\begin{array}{l}\text { Fiscal } \\
\text { year }\end{array}$} & Sales & $\begin{array}{l}\text { Earn- } \\
\text { ings }\end{array}$ & EBITA & $\begin{array}{l}\text { EBITA/ } \\
\text { sales }\end{array}$ & $\begin{array}{l}\text { Fiscal } \\
\text { year }\end{array}$ & Sales & $\begin{array}{l}\text { Earn- } \\
\text { ings }\end{array}$ & EBITA & $\begin{array}{l}\text { EBITA/ } \\
\text { sales }\end{array}$ \\
\hline & $\begin{array}{l}\text { [in Mio } \\
€]\end{array}$ & $\begin{array}{l}\text { [in Mio } \\
€]\end{array}$ & $\begin{array}{l}\text { [in Mio } \\
€]\end{array}$ & & & $\begin{array}{l}\text { [in Mio } \\
€]\end{array}$ & $\begin{array}{l}\text { [in Mio } \\
€]\end{array}$ & $\begin{array}{l}\text { [in Mio } \\
€]\end{array}$ & \\
\hline 2011 & 818 & 0.02 & 0.024 & 0.000 & 2011 & 771 & -1.12 & -1.344 & -0.002 \\
\hline 2012 & 829 & -0.09 & -0.108 & 0.000 & 2012 & 774 & -1.96 & -2.352 & -0.003 \\
\hline 2013 & 827 & -0.23 & -0.276 & 0.000 & 2013 & 762 & -3.87 & -4.644 & -0.006 \\
\hline 2014 & 846 & 0.06 & 0.072 & 0.000 & 2014 & 778 & -3.83 & -4.596 & -0.006 \\
\hline $\begin{array}{l}2015 \\
\text { (est.) }\end{array}$ & 910 & 1.28 & 1.536 & 0.002 & $\begin{array}{l}2015 \\
\text { (est.) }\end{array}$ & 783 & -4.16 & -4.992 & -0.006 \\
\hline
\end{tabular}

EBITA earnings before interest, taxes and, amortization

Participant chose "Industrial Products" and faced positive feedback 


\begin{tabular}{|c|c|c|c|c|c|c|c|c|c|}
\hline \multicolumn{5}{|c|}{ Consumer products } & \multicolumn{5}{|c|}{ Industrial products } \\
\hline \multirow[t]{2}{*}{$\begin{array}{l}\text { Fiscal } \\
\text { year }\end{array}$} & Sales & $\begin{array}{l}\text { Earn- } \\
\text { ings }\end{array}$ & EBITA & $\begin{array}{l}\text { EBITA/ } \\
\text { sales }\end{array}$ & $\begin{array}{l}\text { Fiscal } \\
\text { year }\end{array}$ & Sales & $\begin{array}{l}\text { Earn- } \\
\text { ings }\end{array}$ & EBITA & $\begin{array}{l}\text { EBITA/ } \\
\text { sales }\end{array}$ \\
\hline & $\begin{array}{l}\text { [in Mio } \\
€]\end{array}$ & $\begin{array}{l}\text { [in Mio } \\
€]\end{array}$ & $\begin{array}{l}\text { [in Mio } \\
€]\end{array}$ & & & $\begin{array}{l}\text { [in Mio } \\
€]\end{array}$ & $\begin{array}{l}\text { [in Mio } \\
€]\end{array}$ & $\begin{array}{l}\text { [in Mio } \\
€]\end{array}$ & \\
\hline 2011 & 771 & -1.12 & -1.344 & -0.002 & 2011 & 818 & 0.02 & 0.024 & 0.000 \\
\hline 2012 & 774 & -1.96 & -2.352 & -0.003 & 2012 & 829 & -0.09 & -0.108 & 0.000 \\
\hline 2013 & 762 & -3.87 & -4.644 & -0.006 & 2013 & 827 & -0.23 & -0.276 & 0.000 \\
\hline 2014 & 778 & -3.83 & -4.596 & -0.006 & 2014 & 846 & 0.06 & 0.072 & 0.000 \\
\hline $\begin{array}{l}2015 \\
\text { (est.) }\end{array}$ & 783 & -4.16 & -4.992 & -0.006 & $\begin{array}{l}2015 \\
\text { (est.) }\end{array}$ & 910 & 1.28 & 1.536 & 0.002 \\
\hline
\end{tabular}

EBITA earnings before interest, taxes and, amortization

In 2015, the Board of Directors in fact created a general fund of $€ 20$ million for R\&D and other uses. As Financial Vice President, it is your responsibility to make funding recommendations.

The Board wants to limit additional funds to one division for the first few years, so you should decide how much should be allocated to the originally chosen division.

You can allocate any amount from $€ 0$ to $€ 20$ million to the previously chosen division; any remaining funds would be retained for other uses.

Which amount should be allocated to the originally chosen division? (€0-€20 million):

Here the experiment ends.

Thank you for taking the time to participate.

\section{References}

Bazerman MH, Beekun RI, Schoorman FD (1982) Performance evaluation in a dynamic context: a laboratory study of the impact of a prior commitment to the rate. J Appl Psychol 67:873-876

Bowen MG (1987) The escalation phenomenon reconsidered: decision dilemmas or decision errors? Acad Manage Rev 12:52-66

Bragger JD, Bragger D, Hantula DA, Kirnan J (1998) Hyteresis and uncertainty: the effect of uncertainty on delays to exit decisions. Organ Behav Hum Decis Process 74:229-253

Cheng MM, Schulz AK, Luckett PF, Booth P (2003) The effects of hurdle rates on the level of escalation of commitment in capital budgeting. Behav Res Account 15:63-85

Chenhall R, Morris D (1991) The effect of cognitive style and sponsorship bias on the treatment of opportunity costs in resource allocation decisions. Account Organ Soc 16:27-46

Chewning EG, Harrell A (1990) The effect of information load on decision-makers' cue utilization levels and decision quality in a financial distress decision task. Account Organ Soc 15:527-542

Chow CW, Harrison P, Lindquist T, Wu A (1997) Escalating commitment to unprofitable projects: replication and cross-cultural extension. Manag Account Res 8:347-361

Clinton D (1999) Antecedents of budgetary participation: the effects of organizational situational and individual factors. Adv Manag Account 8:45-70 
Conlon EJ, Parks JM (1987) Information requests in the context of escalation. J Appl Psychol 72:344-350

Denison CA (2009) Real options and escalation of commitment: a behavioral analysis of capital investment decisions. Account Rev 84:133-155

Driver MJ, Brousseau KR, Hunsaker PL (1998) The dynamic decision maker, 2nd edn. In: iUniverse, Lincoln, NE

Elliot WB, Hodge FD, Kennedy JJ, Pronk M (2007) Are M.B.A. students a good proxy for nonprofessional investors? Account Rev 82:139-168

Eppler MJ, Mengis J (2004) The concept of information overload: a review of literature from organization science, accounting, marketing, mis, and related disciplines. Inf Soc 20:325-344

Fehrenbacher DD, Roetzel PG, Pedell B (2018) The influence of culture and framing on investment decision-making: the case of Vietnam and Germany. Cross Cult Strateg Manag 25:763-780

Festinger L (1957) A theory of cognitive dissonance. Stanford University Press, Stanford

Fox FV, Staw BM (1979) The trapped administrator: effects of job insecurity and policy resistance upon commitment to a course of action. Adm Sci Q 24:448-471

Harrell A, Harrison P (1994) An incentive to shirk, privately held information, and manager's project evaluation decisions. Account Organ Soc 19:569-577

Hayes AF (2015) An index and test of linear moderated mediation. Multivar Behav Res 50:1-22. https:// doi.org/10.1080/00273171.2014.962683

Hilbert M, Lopez P (2011) The World's technological capacity to store, communicate, and compute information. Science 332:60-65

Iacobucci D, Posavac SS, Kardes FR, Schneider MJ, Popovich DL (2015) The median split: robust, refined, and revived. J Consum Psychol 25(4):690-704

Kadous K, Sedor LM (2004) The efficacy of third-party consulation in preventing managerial escalation of commitment: the role mental representations. Contemp Account Res 21:55-82

Kanodia C, Bushman R, Dickhaut J (1989) Escalation errors and the sunk cost effect: an explanation based on reputation and information asymmetries. J Account Res 27:59-77

Kiesler CA (1971) The psychology of commitment: experiments linking behaviour to belief. Academic Press, New York

Levitin DJ (2014) The organized mind: thinking straight in the age of information overload. Penguin, New York

Levitin DJ (2015) Why the modern world is bad for your brain. The Guardian, pp 1-18

List JA, Mason CF (2011) Are CEOs expected utility maximizers? J Econom 162:114-123

Miller GA (1956) The magical number seven, plus or minus two: some limits on our capacity for processing information. Psychol Rev 63:81-97

Roetzel PG (2019) Information overload in the information age: a review of the literature from business administration, business psychology, and related disciplines with a bibliometric approach and framework development. Bus Res 12(2):479-522

Roetzel PG, Fehrenbacher DD (2019) On the role of information overload in information systems (IS) success: empirical evidence from decision support systems. In: Proceedings of the international conference on information systems, Munich, Germany

Schroder H, Driver MJ, Streufert S (1967) Human information processing. Holt, Rinehart and Winston, New York

Schultze T, Peiffer F, Schulz-Hardt S (2012) Biased information processing in the escalation paradigm: information search and information evaluation as potential mediators of escalating commitment. $\mathbf{J}$ Appl Psychol 97:16-32

Schulz AK, Cheng MM (2002) Persistence in capital budgeting reinvestment decisions-personal responsibility antecedent and information asymmetry moderator. A Note Account Finance 42:73-86

Schulz-Hardt S, Thurow-Kröning B, Frey D (2009) Preference-based escalation: a new interpretation for the responsibility effect in escalating commitment and entrapment. Organ Behav Hum Decis Process 108:175-186

Seybert N (2010) R\&D capitalization and reputation-driven real earnings management. Account Rev 85:671-693

Shapiro C, Varian HR (2013) Information rules: a strategic guide to the network economy. Harvard Business Press, Cambridge

Sharp DJ, Salter SB (1997) Project escalation and sunk costs: a test of the international generalizability of agency and prospect theories. J Int Bus Stud 28:101-121

Shields MD (1983) Effects of information supply and demand on judgment accuracy: evidence from corporate managers. Account Rev 58:284-303 
Simnet R (1996) The effect of information selection, information processing and task complexity on predictive accuracy of auditors. Account Organ Soc 21:699-719

Simon HA (1971) Designing organizations for an information-rich world. Comput Commun Public Interest 1:40-41

Sleesman DJ, Conlon DE, McNamara G, Miles JE (2012) Cleaning up the big muddy: a meta-analytic review of the determinants of escalation of commitment. Acad Manag J 55:541-562

Sleesman DJ, Lennard AC, McNamara G, Conlon DE (2018) Putting escalation of commitment in context: a multilevel review and analysis. Acad Manag Ann 12:178-207

Staw BM (1976) Knee-deep in the big muddy: a study of escalating commitment to a chosen course of action. Org Behavior Hum Perform 16:27-44. https://doi.org/10.1016/0030-5073(76)90005-2

Staw BM (1981) The escalation of commitment to a course of action. Acad Manag Rev 6:577-587

Sweller J (2011) Cognitive load theory. Psychol Learn Motivation 55:37-76

Tsang EWK, Kwan K-M (1999) Replication and theory development in organizational science: a critical realist perspective. Acad Manag Rev 24:759-778

Whyte G (1991) Diffusion of responsibility: effects on the escalation tendency. J Appl Psychol $76: 408-415$

Publisher's Note Springer Nature remains neutral with regard to jurisdictional claims in published maps and institutional affiliations. 